\title{
Examination of high school students' attitudes towards homework, procrastination behaviors and efficacy beliefs
}

\author{
Canan Koçak Altundağ ${ }^{1, *}$ \\ ${ }^{1}$ Hacettepe University, Department of Mathematics and Science Education, 06800 Ankara, Turkey
}

\begin{abstract}
The aim of this study was to examine the relationship between high school students' academic procrastination behaviors, efficacy beliefs, and attitudes towards homework. This study has shown that students with low academic and/or social efficacy belief engage in more academic procrastination behavior than those with high academic and/or social efficacy belief and that students with high academic, social, and/or emotional efficacy belief have a more positive attitude towards homework than those with low academic, social, and/or emotional efficacy belief. There was no significant statistical difference in academic procrastination behavior based on low or high emotional efficacy belief. This study examines the relationship between high school students' efficacy beliefs, academic procrastination behaviors, and their attitude towards homework in order to address the fact that in the literature there was no study on the correlation between efficacy belief and both academic procrastination and attitude towards homework.
\end{abstract}

\section{Introduction}

Individuals' belief in their ability to accomplish a work or a behavior necessary to successfully accomplish a task is called efficacy belief (or expectancy) [1]. Bandura (1977), who coined the term, defines it briefly as "a person's belief in his or her competency in successfully accomplishing a task": Efficacy is a capacity that needs to be organized and directed in relation to various aims that has cognitive, social, emotional, and behavioral dimensions. Efficacy belief is not only about control over behavior but also about thought processes, motivation, and effective psychological situations [2]. Homework denotes tasks given by teachers for students to complete at home within a specific time frame. Indeed, this is rather effective in reiterating topics in order for students with learning difficulties to gain basic skills [3]. Academic procrastination is a meaninglessly delays delaying the completion or start of academic tasks [4].

Academic procrastination includes behavioral delay and experiencing emotional confusion due to this delay, lack of interest in the task, and decrease in the will to use their capacity concerning the task [5]. When students delay academic tasks, they feel anxiety due to the delay because this delay causes them take more time than necessary and anxiety

\footnotetext{
${ }^{*}$ Corresponding author: canan.kck@gmail.com
} 
increases as tasks are left to the last minute. Students spend time with activities they like and leave other tasks to the last minute. Leaving them to the last minute results in delay [6]. No study that focuses on the combination of academic procrastination, efficacy belief, and attitude toward homework was found in literature. Thus, this paper examines whether high school students' attitudes towards homework and their academic procrastination behaviors differ in relation to their social, academic, and emotional efficacy beliefs. Previous studies have shown that efficacy beliefs have a strong and observable effect on students' thoughts and behaviors, academic procrastination, and attitudes towards homework. High school students' academic procrastination behaviors in the classroom are influenced by many external and internal factors. This study examines high school students' academic procrastination behaviors in their ability to successfully complete a task. The facts that high school students have behavioral delay and due to this delay they experience emotional confusion, that they are reluctant in the face of tasks, and that the decrease in their willingness to use their capacities for the realization of a task were all examined within the frame of efficacy beliefs. This study investigates the attitude dimension of homework, which has positive outcomes in terms of students' attitudes towards school and development of skills in studying and taking responsibility.

\section{Methodology}

This study is a descriptive study that tries to examine the present situation. The aim of this study was to examine the relationship between high school students' academic procrastination behaviors, efficacy beliefs, and attitudes towards homework. The study sample consists of 976 students enrolled in high schools in downtown Ankara.

\subsection{Data Gathering Tools}

In order to determine high school students' efficacy beliefs, the Scale for Efficacy Expectancy in Adolescents designed by Muris (2001) [7] and adapted to Turkish by Çelikkaleli, Gündoğdu, and Kıran-Esen (2006) [8] was used in the study. The factor analyses conducted for validity studies showed that the scale has the same three-factor structure that the original does. These factors are: academic efficacy expectancy (AEE), social efficacy expectancy (SEE), and emotional efficacy expectancy (EEE). In order to determine students' academic procrastination behaviors, the Academic Procrastination Scale developed by [9] Çakıcı (2003) was used. The Chronbach alpha reliability coefficient of the scale was found to be .92. In addition, the Attitude Toward Homework Scale developed by Yücel (2004) [10] and re-designed by Önen and Koçak (2013) [11] was used. The Cronbach alpha reliability coefficient of this scale was .85 .

\subsection{Data and Analysis}

In order to test whether high school students' attitudes towards homework and their academic procrastination behavior vary in relation to their social, academic, and emotional efficacy beliefs, scores from these three areas were each divided into three categories: low, moderate, and high using the average of the scores from each sub-scale and their standard deviation. Variance analysis (ANOVA) was conducted in order to see whether the examined characteristics varied by group. In addition, arithmetic average values were examined when necessary in the analysis of data. The statistics program SPSS was used in data analysis. 


\section{Findings}

ANOVA was conducted in order to determine high school students' score differentiation of academic procrastination behavior in relation to their efficacy beliefs. Obtained findings were summarized in Table 1.

Table 1. ANOVA results of high school students' differentiation of academic procrastination behavior in relation to their efficacy beliefs.

\begin{tabular}{|c|c|c|c|c|c|c|c|c|}
\hline $\begin{array}{c}\text { Efficacy } \\
\text { Belief }\end{array}$ & Categories & Mean & ss & Groups & $\begin{array}{c}\text { Sum of } \\
\text { Squares }\end{array}$ & $\begin{array}{c}\text { Mean } \\
\text { Square } \\
\end{array}$ & $\mathbf{F}$ & $\mathbf{p}$ \\
\hline \multirow{3}{*}{$\begin{array}{l}\text { Academic } \\
\text { Efficacy }\end{array}$} & Low & 3.07 & .494 & $\begin{array}{l}\text { Between } \\
\text { Groups }\end{array}$ & 40.01 & 20 & \multirow{3}{*}{54.6} & \multirow{3}{*}{.00} \\
\hline & Moderate & 2.80 & .555 & $\begin{array}{l}\text { Within } \\
\text { Groups }\end{array}$ & 356.10 & \multirow{2}{*}{.36} & & \\
\hline & High & 2.56 & .756 & Total & 396.12 & & & \\
\hline \multirow{3}{*}{$\begin{array}{c}\text { Social } \\
\text { Efficacy }\end{array}$} & Low & 2.90 & .562 & $\begin{array}{l}\text { Between } \\
\text { Groups }\end{array}$ & 4.81 & 2.4 & \multirow{3}{*}{5.98} & \multirow{3}{*}{.00} \\
\hline & Moderate & 2.81 & .633 & $\begin{array}{l}\text { Within } \\
\text { Groups }\end{array}$ & 391.31 & \multirow{2}{*}{.40} & & \\
\hline & High & 2.74 & 699 & Total & 396.12 & & & \\
\hline \multirow{3}{*}{$\begin{array}{c}\text { Emotional } \\
\text { Efficacy }\end{array}$} & Low & 2.85 & .627 & $\begin{array}{l}\text { Between } \\
\text { Groups }\end{array}$ & 1.038 & .519 & \multirow{3}{*}{1.27} & \multirow{3}{*}{.27} \\
\hline & Moderate & 2.83 & .616 & $\begin{array}{l}\text { Within } \\
\text { Groups }\end{array}$ & 395.084 & \multirow{2}{*}{.406} & & \\
\hline & High & 2.77 & .666 & Total & 396.123 & & & \\
\hline
\end{tabular}

The findings in Table 1 show that students' academic procrastination scores differ in a statistically significant way (.05) that correlates to their academic efficacy beliefs. In the Scheffe test done to determine the source of the difference, it was determined that students who have low academic efficacy belief have more academic procrastination behavior than those who have high academic efficacy belief. In addition to this, variance analysis results indicate that the students' academic procrastination scores differ in a statistically significant way related to their social efficacy beliefs. In the Scheffe test done to determine the source of the difference, it was determined that students who have low social efficacy belief have more academic procrastination behavior than those who have high social efficacy belief. The results show that the academic procrastination scores of the high school students in the sample do not show a statistically significant difference related to students' emotional efficacy belief.

Table 2 shows that students who have low academic efficacy belief have a more negative attitude toward homework and, conversely, that students who have high academic efficacy belief have a more positive attitude toward homework. Indeed, the Scheffe test conducted reveals the same correlation. The variance analysis, which was done to determine whether there was a statistically significant difference between score averages, showed that students with high social efficacy belief have a more positive attitude towards homework than those with low social efficacy belief. The results also show that students with high emotional efficacy belief have a more positive attitude towards homework than those with low emotional efficacy belief. 
Table 2. ANOVA results of high school students' score differentiation of attitude toward homework in relation to their efficacy beliefs.

\begin{tabular}{|c|c|c|c|c|c|c|c|c|}
\hline Efficacy Belief & Categories & Mean & ss & Groups & $\begin{array}{c}\text { Sum of } \\
\text { Squares }\end{array}$ & $\begin{array}{c}\text { Mean } \\
\text { Square }\end{array}$ & $\mathbf{F}$ & $\mathbf{p}$ \\
\hline \multirow{3}{*}{$\begin{array}{l}\text { Academic } \\
\text { Efficacy }\end{array}$} & Low & 3.13 & .58 & $\begin{array}{l}\text { Between } \\
\text { Groups }\end{array}$ & 66.40 & 33.20 & \multirow{3}{*}{99} & \multirow{3}{*}{.00} \\
\hline & Moderate & 3.47 & .52 & $\begin{array}{l}\text { Within } \\
\text { Groups }\end{array}$ & 325.5 & \multirow{2}{*}{.33} & & \\
\hline & High & 3.79 & .63 & Total & 392 & & & \\
\hline \multirow{3}{*}{ Social Efficacy } & Low & 3.26 & .58 & $\begin{array}{l}\text { Between } \\
\text { Groups }\end{array}$ & 23.81 & 11.90 & \multirow{3}{*}{31.4} & \multirow{3}{*}{.00} \\
\hline & Moderate & 3.46 & .59 & $\begin{array}{l}\text { Within } \\
\text { Groups }\end{array}$ & 368.19 & \multirow{2}{*}{.378} & & \\
\hline & High & 3.64 & .66 & Total & 392.00 & & & \\
\hline \multirow{3}{*}{$\begin{array}{l}\text { Emotional } \\
\text { Efficacy }\end{array}$} & Low & 3.21 & .57 & $\begin{array}{l}\text { Between } \\
\text { Groups }\end{array}$ & 41.19 & 20.59 & \multirow{3}{*}{57.1} & \multirow{3}{*}{.00} \\
\hline & Moderate & 3.43 & .56 & $\begin{array}{l}\text { Within } \\
\text { Groups }\end{array}$ & 350.81 & \multirow{2}{*}{.361} & & \\
\hline & High & 3.71 & .65 & Total & 392.00 & & & \\
\hline
\end{tabular}

\section{Discussion}

This study determined that students with low academic efficacy belief have more academic procrastination behavior than those with high academic efficacy. While a person's low efficacy belief causes avoidance of the behavior, high efficacy belief causes one to incline towards a behavior [12] (Betz \& Luzzo 1996). Social efficacy belief is one of the most important dimensions of efficacy expectancy, and it greatly affects the way a person behaves [13, 14] (Çakıcı, 2010). Efficacy belief has a significant role in a person's receiving an effective education. Efficacy affects whether individuals will perform a behavior or not, how much effort they will expend in order to successfully complete a behavior, and how persistent they will be in the face of obstacles [8] (Kiran-Esen \& Çelikkaleli, 2008). This study determined that students with low social efficacy beliefs have more academic procrastination behavior than those with high social efficacy belief. In Bandura's words, social efficacy belief denotes "individuals' self-expectancy about a performance which was done in relation to personal skill in interpersonal relations." This study showed that there is no statistically significant difference in academic procrastination behavior in relation to emotional efficacy belief. Emotional efficacy belief is related to belief in one's ability to overcome stressful situations. Individuals with high efficacy beliefs prefer to overcome more complex and difficult tasks. Low efficacy belief is related to depression, anxiety, and helplessness. People with high efficacy belief see the obstacles not as dangers to be avoided but as problems to be solved. They pick difficult tasks and are determined to reach the end. People with high emotional efficacy belief find a variety of interests and thus enjoy life. When faced with stressful situations, they have a strong belief in their ability to overcome them [15] (Singh \& Udainiya, 2009). This study revealed that students with high social, academic, and emotional efficacy have a more positive attitude towards homework than students with low academic, social, and emotional efficacy beliefs. Indeed, Corno's (2000) [16] study indicated that homework contributes to increasing social feelings. Thelwell, Lane, and Weston (2007) revealed that high efficacy belief accompanies positive emotional situations. Because there are no studies in the literature where efficacy 
beliefs, academic procrastination behavior, and attitude towards homework are examined together, more detailed and different studies should focus on this topic [17].

\section{References}

1. A. Bandura, Self-efficacy: Toward a unifying theory of behavioral change. Psychological Review, 84(2):191-215, (1977)

2. A. Bandura, Exercise of personal and collective efficacy in changing societies. In A Bandura (ed). Self-efficacy in changing societies. New York, NY: Cambridge University Press, (1995)

3. M.S. Rosenberg, The effects of daily homework assignments on the acquisition of basic skills by students with learning disabilities. Journal of Learning Disabilities, 22:314-323, (1989)

4. W.J. Knaus ,Do it now! Break procrastination habit. New York, NY: John Wiley \& Sons, Inc, (1998)

5. N.N Milgram, S. Marshevsky, Correlates of academic procrastination: Discomfort, task aversiveness and task capability. Journal of Psychology, 129:145-155, (1995)

6. C.H. Lay, At last, my research article on procrastination. Journal of Research in Personality, 20:474-495, (1986)

7. P. Muris, A brief questionnaire for measuring self-efficacy in youths. Journal of Psychopathology and Behavioral Assessment, 23(3):145-149, (2001)

8. Ö. Çelikkaleli M. Gündoğdu B. Kıran Esen, Questionnaire for measuring self-efficacy in youths: Validity and reliability study of Turkish form. Eurasian Journal of Educational Research, 25:62-72, (2006)

9. D.Ç. Çakıcı, An Examination of the general procrastination behavior and academic procrastination behavior in high-school and university students. Master's thesis. Ankara: Ankara University, (2003)

10. S., Yücel, The analysis of the attitudes of secondary education students towards chemistry assignments. Gazi University Journal of Education, 24(1):147-159, (2004)

11. A.S. Önen, C. Koçak, Exploratory and confirmatory factor analysis study for the scale of attitudes towards chemistry homework. Middle Eastern \& African Journal of Educational Research, 6:44-59, (2013)

12. N.E. Betz, D.A. Luzzo DA, Career assessment and the career decision-making selfefficacy scale. Journal of Career Assessment, 4:413-428, (1996)

13. D. Çakıcı, The analysis of social self-efficacy and self-esteem levels of ninth and tenth grade sports and general high school students. Master's thesis. Mersin: Mersin University, (2010)

14. F. Alkan, Development of Chemistry Laboratory Self-Efficacy Beliefs Scale. Journal of Baltic Science Education, 15 (3), 350-359, (2016)

15. B. Singh, R. Udainiya ,Self-efficacy and well-being of adolescents. Journal of the Indian Academy of Applied Psychology, 35(2):227-232, (2009).

16. L.Corno, Looking at homework differently. The Elementary School Journal, 100(5):529-548, (2000)

17. R.C. Thelwell, A.M. Lane, N.J.V Weston, Mood states, self-set goals, self-efficacy and performance in academic examinations. Personality and Individual Differences, 42:673-583, (2007) 